\title{
ÚTMUTATÓ A VALÓSÁG VIZSGÁLATÁHOZ
}

\section{DoBó ISTVÁN}

\author{
a Budapesti Corvinus Egyetem \\ tanársegédje \\ istvan.dobo@uni-corvinus.hu
}

„A tudományok világában mindannyian olyanok vagyunk, mint a játszó gyermek, aki a tudás partján itt-ott felemel egy érdekes kavicsot, míg az igazság nagy óceánja ismeretlenül terül el a szeme elött."

Isaac Newton

Újabb értékes kötet jelent meg pedagógiai kutatásmódszertani eszköztárunk bővítéséhez az Eötvös Kiadó gondozásában. Sántha Kálmán a kvalitatív pedagógiai kutatások mintavételi kérdéseit vizsgáló müve után (Sántha, 2006) ezúttal a kvalitatív vizsgálatok széles módszertani eszköztárát gyüjti egy kötetbe. A könyv azonban jóval több, mint új kutatási technikák bemutatása. Olyan modern kutatói szemlélet világába vezeti be olvasóját, ahol a kutató kilép a zárt, könnyen mérhető és számszerüsíthető valóságok dimenziójából a tudományos vizsgálódásnak azon területeire, amelyek „,betekintést engednek a vizsgált személyek élményeibe, lehetővé teszik a világukat befolyásoló nézetek és a gondolkodásuk feltárását, és alkalmasak az egyedi szituációk, jelenségek értelmezésére, magyarázatára is". (Sántha, 2009, 52. o.). Olyan merész kutatási problémák vizsgálatáról van itt szó, amelyek elfordulnak az általánostól, a tipikustól, ezzel szemben az egyedi esetekkel való foglalkozás fontosságát hangsúlyozzák. Olyan kutatásokra bíztat a könyv, amelyek ott is képesek észrevenni pedagógiai problémákat és izgalmas kérdéseket, ahol más vizsgálatok nem látnak semmi érdekeset. Azokhoz az olvasókhoz szól tehát, akik fogékonyak az észrevétlenül hátrahagyott tudományos nyomok és jelek követésére.

Pedagógiai kutatók, tanárjelöltek, doktorandusz hallgatók és gyakorló tanárok mellett azonban a társadalomtudományok más területei iránt érdeklődő olvasók számára is újszerü és hasznos elméletekkel, módszerekkel szolgálhat a kötet. Szükség is van e munkára, hiszen a kvalitatív kutatások kíváncsi kérdésfeltevésükkel, sokoldalú problémaelemzésükkel és változatos módszertani kultúrájukkal egyre elfogadottabbá és népszerübbé válnak a pedagógiai kutatások területén. Olyan könyv ez, ami az olvasó szakmai tudásának bővítésén túl gondolkodásra is serkenti az olvasót, hiszen nem csak arra kap választ, hogy milyen a jó kvalitatív kutatás, ami képes elrugaszkodni az ismétlődő, rutinszerủ vizsgálódástól, de arra is ösztönöz, 
hogy az újszerủ eredmények mellett azt se felejtsük el, hogy az igazi kutatás lehet könnyed és szórakoztató munka eredménye is. A könyv izgalmas olvasmány azok számára, akik szakmai kihívásnak tekintik új kutatói módszerek megismerését és alkalmazását, de azok számára is, akik elméleti megerősítést keresnek egyedi, rendhagyónak tünő kutatási ötleteikhez.

Az első fejezetben a kvalitatív paradigma megjelenését és történeti fejlődését vizsgálva hamar belátható, hogy a kvalitatív kutatások területe nem csupán módszertani újdonságokban merül ki, hanem egy modern tudományelméleti filozófia húzódik meg mögötte. A kötet nagy pozitívuma, hogy a sokoldalú módszertani elemzés mellett újszerü szemléletmóddal közelíti meg a témát. A kvalitatív paradigmán belül gondolkodó és vizsgálódó kutatónak ugyanis nem elegendő megismerni a módszereket, tisztáznia kell azt is, hogy mit ért „a valóság” fogalma alatt, és milyen lehetőségek léteznek ennek megismerésére.

A Szerző az első részben rámutat arra, hogy a társadalmi- és a humán valóság megfigyelése sajátos jellemzőkkel rendelkezik, melyek sok tekintetben eltérnek a hagyományos természettudományos vizsgálatoktól. Más metodikára és más kutatói hozzáállásra van szükség ott, ahol a kutatások alanyai gondolkodnak, éreznek, beszélnek, cselekedeteik mozgatórugóját, kijelentéseik tartalmát és emberi kapcsolataikat nem egyszerüen ok-okozati összefüggések, hanem láthatatlan kulturális motívumok, személyes élettörténetek, vagy éppen spontán helyzetek szövevényes hálózatai határozzák meg. Bonyolult, személyes valóságokkal áll tehát szemben a pedagógiai kutató, aki - akár megfigyelőként, akár elemzőként - maga is szubjektív résztvevője a vizsgált jelenségeknek.

Mindez nem jelenti azt, hogy ne lehetne modellezni, leegyszerüsíteni és tudományos módszerekkel megragadni összetett és életszerú pedagógiai problémákat. Ehhez azonban új kutatói attitüdre és megfelelő kutatási gyakorlatra van szükség. Ilyen nyitott, viszonylag kötetlen keretek között zajló, nem lineáris szerkezetü kutatási folyamatot vázol fel Sántha Kálmán a második fejezetben. Újszerü kérdéskultúra áll a kvalitatív kutatási folyamat kezdetén, ami újraértelmezi az adatgyüjtés és az adatelemzés menetét, a hipotézisalkotás szerepét, a szakszerü dokumentáció és a körültekintő elemzés kritériumait, valamint az általánosíthatóság lehetőségét is. A kvalitatív felfogás a tudományos kutatásra - akárcsak magára a valóságra - nem úgy tekint, mint kényelmes, biztonságos helyre, hanem olyan nyitott és rugalmas rendszerre, ami feltételezi a rendszeres kutatói visszacsatolást, valamint a vizsgált problémára vonatkozó folyamatos kritikus kérdésfelvetéseket és értelmezéseket.

„Akinek a kalapács az egyetlen szerszáma, az minden problémában szeget lát" üzeni Paul Watzlawick, a konstruktivizmus neves képviselöje. A harmadik fejezetben elérkezik az olvasó a könyv egyik legfontosabb részéhez, a konkrét módszerek részletes leírásához. Ez az a pont, ahol az olvasó válogathat a kutatói eszközökből, és megtöltheti pedagógiai szerszámosládáját a számára közel álló, és az általa vizsgált problémát legjobban megragadó módszerekkel. Részletes képet kaphatunk e feje- 
zetben a támogatott felidézés, a kognitív térkép, a metaforakutatás, az interjú és a beavatkozás nélküli vizsgálatok logikájáról és menetéről. A Szerző az egyes kvalitatív módszereket körültekintően járja körül, ,[...] hiszen a módszerek használata döntően befolyásolja a kutatási folyamatot, az adatfelvételt, -elemzést és az eredményeket." (51. o.) Nem csak lényegüket, előnyeiket és korlátozó tényezőiket ismerhetjük itt meg, de a Szerző által bemutatott életszerü iskolai helyzetek és kutatási példák révén bepillanthatunk az egyes módszerek gyakorlatban történő megvalósításának lehetőségeibe is. Mindezt kiegészíti minden egyes technika esetén az egyes eljárásokat korábban már alkalmazó kutatások témájának, szerzőinek és publikációinak listája is.

A negyedik fejezetben a Szerző megvizsgálja és újraértelmezi annak elméleti lehetőségeit, hogy miként alkalmazhatók együtt a kvalitatív és a kvantitatív módszerek a kutatások során. Lehet-e matematikailag számszerúsíteni szövegeket, interjúkérdésekre adott válaszokat, illetve lehet-e adatsorokat, trendeket kvalitatív módon interpretálni? Sántha Kálmán meggyőzően érvel amellett, hogy a két kutatási paradigma nem csak egymástól függetlenül, párhuzamosan elvégezve segítheti a kutatók munkáját, de egymással kombinálva olyan dinamikus kutatási folyamatot hozhat létre, amelyben a két megközelítés egyenrangúan egészíti ki egymást. A könyv nem úgy tekint a két kutatási paradigmára, mint két ellentétes mozgalom képviselőire. Abból indul ki, hogy egy kutatás mindig korábbi eredmények továbbkutatása, olyan alapokra való építkezés, amit mások munkája, vagy saját előzetes tapasztalataink és ismereteink készítettek elő. Olykor ezek az alapok nagyszerü eredményekig vezethetik a kutatót, máskor tévutakra. Elképzelhető, hogy egy pedagógiai problémára keresett válaszra a kvalitatív és a kvantitatív eljárás adataiból és elemzéséből egymást megerősítő, kiegészítő, vagy éppen egymásnak ellentmondó következtetéseket vonhatunk le. A Szerző mégis arra bátorítja a kutatókat, hogy mind a két technikát érdemes használni, hiszen az egymásnak ellentmondó eredmények is folyamatosan pontosítják, és ez által előre lendítik a kutatást sokrétü és biztos alapokon nyugvó tudományos eredmények felé.

Ezt a gondolatmenetet vezeti tovább Sántha Kálmán a kvalitatív metodológiai elveket taglaló ötödik fejezetben is. „Léteznek-e egyáltalán kvalitatív elvek?” - teszi fel a kérdést a Szerző a fejezet elején. (106. o.) A kvalitatív kutatások felé néha még mindig bizonytalansággal fordulnak a kutatók, és vádak is érhetik e kutatásokat, miszerint túlságosan tudománytalanok, egyediek, nem kellően objektívak, nem képesek megvalósítani a tudományos érvényesség kritériumát. A tudomány azonban ma már nem kizárólag arról ismerszik meg, hogy megbízható skálákon mérhető, számszerüsíthető, minél inkább általánosítható eredményekkel szolgál. Sántha Kálmán e fejezetben jó érzékkel mutat rá arra, hogy a kvalitatív metodológia rugalmas és szabad felfogása egyáltalán nem azt jelenti a kutató számára, hogy azt fedezhet fel, amit csak akar. A fejezetben a Szerző bebizonyítja, hogy igenis beszélhetünk tudományos objektivitásról, megbízhatóságról és érvényességről a kva- 
litatív kutatások elején is. Ehhez azonban e klasszikus tudományos kritériumok kibővítésére, illetve átértelmezésére van szükség. A fejezet széleskörü kritériumkatalógust tartalmaz, ami nagyban segítheti a kvalitatív kutatások egzakt tudományos folyamatként való felépítését, lehetővé téve ez által megalapozott következtetések levonását.

A társadalomtudományi - és különösen a pedagógiai - kutatások esetén nem hagyható figyelmen kívül az sem, hogy „minden vizsgálat beavatkozás az érintettek életébe". (125. o.) Ezért etikai vonatkozásai is vannak a kvalitatív kutatásnak, amelyekröl a hatodik fejezetben olvashatunk. A hetedik fejezetben táblázatos és vázlatos formában összegzi a Szerző a korábbi fejezetek legfontosabb üzeneteit és tanulságait. A könyv nyolc fejezete így a történeti-filozófiai megközelítések tisztázása, majd a módszerek elemzése után végül összegzi, keretbe foglalja a kötet legfontosabb tanulságait. Az egyes fejezetek elején a Szerző feltünteti a fejezetek főbb tartalmi kérdéseit, problémaköreit. A fejezetek végén pedig a fö kérdések, feladatok és kulcsfogalmak összefoglalásával rendszerezi az egyes részek legfontosabb gondolatait. Az olvasót a céltudatos keresésben a név- és tárgymutató mellett a szövegben jelzett honlapok hivatkozásai is segítik.

A tudományos fejlődést évszázadokon keresztül tudományos eredmények folyamatos felhalmozódásaként képzelték el, olyan tevékenységnek, mint amilyen az új területek felfedezése volt a világ felfedezésekor. A hipotetikus gondolkodás és a paradigmák megjelenése alapvetően megváltoztatta a tudományok lineáris fejlődéséröl alkotott képet, ami ahhoz vezetett, hogy a tudomány világa nem egy magányos elefántcsonttoronyhoz, hanem sokkal inkább egy nyitott parlamenthez hasonlítható, amelyben különböző paradigmák képviselői csapnak össze, és mérettetik meg érveiket más paradigmák képviselőivel. Vannak kutatók, akik az uralkodó paradigmák igazolásán dolgoznak, és vannak olyanok, akik olyan problémakörök iránt érdeklődnek, amelyek nem ragadhatók meg, vagy nem magyarázhatóak az uralkodó paradigmákon belül. Sántha Kálmán könyve nagymértékben hozzájárul ahhoz, hogy a kvalitatív pedagógiai kutatások megszilárdítsák helyüket a neveléstudományban, és egyúttal bíztatást és eszközöket is nyújt azoknak a kutatóknak, akik eredeti és egyedi jelenségek vizsgálatára vállalkoznak.

Sántha Kálmán: Bevezetés a kvalitatív pedagógiai kutatás módszertanába. Eötvös József Könyvkiadó, 2009, 162 oldal

\section{Irodalom}

Sántha Kálmán (2006): Mintavétel a kvalitativ pedagógiai kutatásban. Kutatás-módszertani Kiskönyvtár. Gondolat Kiadó, Budapest. 